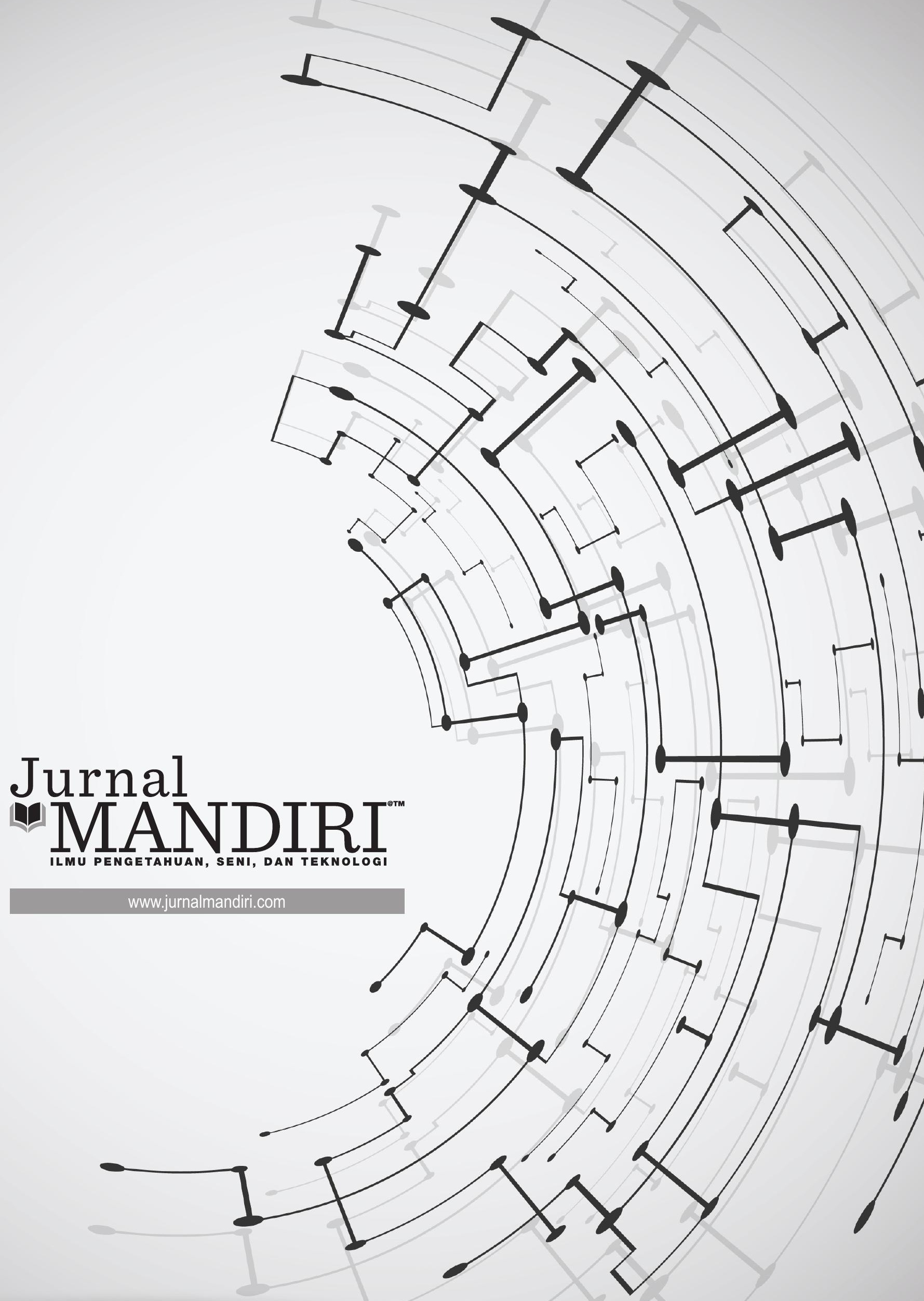


ISSN : 2580-3220, E-ISSN : 2580-4588

J. Mandiri., Vol. 4, No. 1, Juni 2020 (94 - 104)

(C)2018 Lembaga Kajian Demokrasi

dan Pemberdayaan Masyarakat (LKD-PM)

DOI : https://doi.org/10.33753/mandiri.v4i1.107

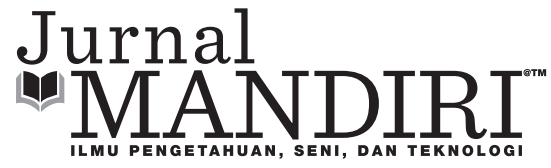

\title{
Pengaruh Kualitas Produk dan Harga Terhadap Keputusan Pembelian Tupperware (Studi Kasus Ibu Rumah Tangga di Perumahan Kunciran, Tangerang)
}

\author{
Ivan Putranto \\ Fakultas Ekonomi, Universitas Pamulang \\ ivanputranto21@gmail.com \\ Kartoni \\ Fakultas Ekonomi, Universitas Pamulang \\ kartoni86@gmail.com
}

\begin{abstract}
Abstrak
Penelitina ini bertujuan untuk mengetahui pengaruh kualitas produk terhadap keputusan pembelian Tupperware, mengetahui pengaruh harga terhadap keputusan pembelian Tupperware, dan mengetahui pengaruh kualitas produk dan harga terhadap keputusan pembelian Tupperware. Metode yang digunakan adalah deskriptif dengan pendekatan asosiatif. Sampling yang digunakan sampling jenuh, sedangkan untuk mendapatkan data dilakukan dengan menyebar kuesioner kepada 60 responden yang kemudian dianalisis pengaruh secara parsial dan simultan dengan menggunakan analisis regresi, koefisien determinasi serta pengujian hipotesis dengan uji $t$ dan uji F. Hasil penelitian menunjukkan bahwa: Pengaruh kualitas produk terhadap keputusan pembelian sebesar 24,6\%, pengaruh ini positif dan signifikan. Pengujian hipotesis diperoleh $t_{\text {hitung }}>t_{\text {tabel }}$ atau $(4,852>1.296)$ dan probability $0,000<0,1 \mathrm{H}_{1}$ diterima artinya terdapat pengaruh yang positif dan signifikan antara kualitas produk terhadap keputusan pembelian. Pengaruh harga terhadap keputusan pembelian sebesar 49,7\%, pengaruh ini positif dan signifikan. Pengujian hipotesis diperoleh (6,370 $>1.296$ ) dan probability 0,000 $<0,1 \mathrm{H}_{1}$ diterima artinya terdapat pengaruh yang positif dan signifikan antara harga terhadap keputusan pembelian. Hasil uji simultan kualitas produk dan harga memiliki pengaruh yang positif dan signifikan terhadap keputusan pembelian dengan kontribusi pengaruh sebesar 40,4\%. Pengujian hipotesis diperoleh $(23,457>2.80)$ dan probability $0,000<0,1$ sehingga $H_{1}$ diterima artinya terdapat pengaruh yang positif dan signifikan antara kualitas produk dan harga terhadap keputusan pembelian. Berdasarkan hasil penelitian dapat disimpulkan bahwa secara parsial kualitas produk berpengaruh terhadap keputusan pembelian Tupperware, harga berpengaruh terhadap keputusan pembelian Tupperware dan secara simultan kualitas produk dan harga berpengaruh terhadap keputusan pembelian Tupperware.
\end{abstract}

Kata Kunci : Kualitas Produk, Harga dan Keputusan Pembelian

\begin{abstract}
This research aims to determine the effect of product quality on Tupperware purchasing decisions, determine the effect of prices on Tupperware purchase decisions, and determine the effect of product quality and price on Tupperware purchase decisions. The method used is descriptive with an associative approach. Sampling used saturated sampling, while to get data done by distributing questionnaires to 60 respondents who then analyzed the influence partially and simultaneously using regression analysis, coefficient of determination and hypothesis testing with $t$ test and $f$ test. The results showed that: The effect of product quality on purchasing decisions of $24.6 \%$, this effect is positive and significant. Hypothesis testing obtained $t_{\text {count }}>t_{\text {table }}$ or $(4.852>1,296)$ means that there is a positive and significant effect between product quality on purchasing decisions. The influence of prices
\end{abstract}


on purchasing decisions by $49.7 \%$, this effect is positive and significant. Hypothesis testing is obtained (6,370> 1,296) meaning that there is a positive and significant influence between the price of the purchasing decision. Simultaneous test results of product quality and price have a positive and significant influence on purchasing decisions with a contribution of 40.4\%. Hypothesis testing is obtained (23.457> 2.80), meaning that there is a positive and significant influence between product quality and price on purchasing decisions. Based on the results of the study it can be concluded that partially and simultaneously the quality and price of the product is influences the purchase decision of Tupperware.

Keywords : Product Quality, Price and Purchase Decisions

\section{PENDAHULUAN}

Kesadaran masyarakat akan pentingnya pelestarian lingkungan semakin meningkat. Peningkatan ini dilihat dari adanya kekhawatiran terjadinya bencana yang mengancam lingkungan hidup, bukan hanya kesehatan, bahkan sampai pada kelangsungan hidup manusia dan keturunannya. Beberapa konsumen mulai lebih selektif dalam melakukan pemilihan dan pembelian produk. Perubahan ini dijadikan peluang perusahaan untuk bersaing secara ketat untuk memenuhi kebutuhan dan keinginan konsumen. Produsen sedikit demi sedikit mulai beralih menggunakan bahan baku produksi yang tidak merusak lingkungan atau dengan istilah lain bahan yang ramah terhadap lingkungan. Perusahaan yang menerapkan isu peduli terhadap lingkungan hidup dalam aktivitas produksinya menimbulkan fenomena baru dalam dunia pemasaran berupa strategi pemasaran ramah lingkungan.

Pemasaran hijau merupakan topik yang banyak dibicarakan saat ini. Banyak perusahaan yang berpendapat bahwa pemasaran hijau merupakan sebuah ide yang bagus dan berpotensi untuk kedepannya serta menerapkan sistem pemasaran ramah lingkungan guna untuk meningkatkan penjualan. Pemasaran hijau perlu diterapkan pada dunia pemasaran dikarenakan adanya ketertarikan para konsumen mengenai kepedulian terhadap lingkungan. Menurut Arseculeratne and Yazdanifard (2014: 136) menyatakan konsep pemasaran hijau mencakup karakteristik tertentu seperti pemasaran produk yang aman bagi lingkungan, pengembangan dan pemasaran produk yang dapat meminimalkan bahaya bagi lingkungan, memproduksi, mempromosikan, dan kemasan produk dengan cara yang sesuai sehingga dapat melindungi lingkungan. Manfaat yang didapatkan dengan adanya pemasaran ramah lingkungan adalah menghasilkan produk-produk yang menggunakan bahan baku yang ramah terhadap lingkungan.

Tupperware adalah perusahaan multinasional yang memproduksi dan memasarkan produk plastik berkualitas untuk rumah tangga. Karakteristik dari produk Tupperware adalah bersifat Eco Green Design, higienis serta ramah lingkungan. Produk Tupperware terbuat dari bahan plastik berkualitas terbaik, produk plastik yang berkualitas tinggi, higienis, aman dan sehat serta kedap udara, tidak mengandung zat kimia beracun dan sudah memenuhi standar dari beberapa badan dunia seperti FDA (Food and Drug Administration) Amerika, European Food Safety Authority (Eropa), Japan Food Safety Commision (Jepang), sehingga selain aman digunakan berkali-kali untuk makanan dan minuman (Food Grade) juga ramah lingkungan, higienis serta eco design karena produk Tupperware yang rusak bisa didaur ulang menjadi produk lain seperti bangku plastik, pot tanaman, tempat sampah dan sebagainya.

Produk memiliki arti penting bagi perusahaan karena tanpa adanya produk perusahaan tidak dapat melakukan apapun dari usahanya. Pembeli akan membeli produk jika merasa cocok, karena produk harus disesuaikan dengan keinginan atau kebutuhan pembeli agar pemasaran produk berhasil. Salah satu keunggulan dalam persaingan ini terutama adalah kualitas produk yang dapat memenuhi kebutuhan dan keinginan konsumen, bila tidak sesuai dengan spesifikasi maka produk akan ditolak atau tidak diterima. Kondisi pelanggan yang semakin kritis dalam hal kualitas akan memaksa perusahaan untuk dapat mempertahankan dan meningkatkan kualitas 
produk agar dapat bersaing dengan perusahan lainnya.

Menurut Kotler dan Armstrong (2012: 283) arti dari kualitas produk adalah kemampuan sebuah produk dalam memperagakan fungsinya, hal itu termasuk keseluruhan durabilitas, reliabilitas, ketepatan, kemudahan pengoperasian dan reparasi produk juga atribut produk lainnya. Kualitas produk, merupakan bagian terpenting dalam menunjang suatu penjualan produk di sebuah perusahaan, begitu pun produk Tupperware yang secara konsisten menjaga kualitas produknya agar konsumen yang membeli merasa puas setelah menggunakan produk tersebut. Salah satu cara produk Tupperware dalam menjaga kualitas terhadap produk Tupperware adalah dengan uji layak pakai setiap produknya sebelum dipasarkan, hal ini dilakukan agar produk dapat bersaing dipasaran dan memiliki citra yang baik bagi konsumen. Permasalahan terhadap produk Tupperware masih banyaknya jenis plastik Tupperware yang tidak tahan panas untuk model lama, sehingga masih banyak konsumen yang ragu untuk membeli lagi, hal ini disebabkan karena banyaknya konsumen yang memutuskan untuk beralih membeli produk industri pesaing. Selain kualitas produk, harga juga diduga dapat mempengaruhi keputusan pembelian.

Harga merupakan salah satu penentu keberhasilan suatu perusahaan karena harga menentukan seberapa besar keuntungan yang akan diperoleh perusahaan dari penjualan produknya baik berupa barang maupun jasa. Menurut Hasan (2008: 298) berpendapat bahwa harga adalah segala bentuk biaya moneter yang dikorbankan oleh konsumen untuk memperoleh, memiliki, memanfaatkan sejumlah kombinasi dari barang beserta pelayanan dari suatu produk.

Tabel 1. Perbandingan Harga Tupperware \& Twin Tulipware
\begin{tabular}{|c|l|l|l|l|}
\hline No & $\begin{array}{c}\text { Jenis Produk } \\
\text { Tupperware }\end{array}$ & \multicolumn{1}{|c|}{2017} & \multicolumn{1}{c|}{2018} & 2019 \\
\hline 1 & Snack It & Rp.150.000 & $\begin{array}{l}\text { Twin Tulipware } \\
\text { Bottle 750 ml }\end{array}$ & Rp. 120.000 \\
\hline 2 & Mosaic Bread Lover & Rp. 95.000 & $\begin{array}{l}\text { Twin Tulipware } \\
\text { Tumbler 450 ml }\end{array}$ & Rp. 66.000 \\
\hline 3 & Mosaic Sweet Saver & Rp. 125.000 & $\begin{array}{l}\text { Twin Tulipware } \\
\text { Kotak Makan }\end{array}$ & Rp. 78.000 \\
\hline 4 & Mosaic Snack Stor & Rp. 155.000 & $\begin{array}{l}\text { Twin Tulipware TLT } \\
\text { Spalsh 110 ml }\end{array}$ & Rp. 80.000 \\
\hline
\end{tabular}

\begin{tabular}{|c|l|l|l|l|}
\hline 5 & Giant Canister & Rp.216.000 & $\begin{array}{l}\text { Twin Tulipware } \\
\text { Wadah Makanan } \\
\text { Frozzy cup (2) }\end{array}$ & Rp. 145.000 \\
\hline 6 & $\begin{array}{l}\text { Large Mosaic } \\
\text { Canister }\end{array}$ & Rp. 131.000 & $\begin{array}{l}\text { Twin Tulipware Big } \\
\text { Tumbler (2) }\end{array}$ & Rp. 98.000 \\
\hline 7 & $\begin{array}{l}\text { Medium Mosaic } \\
\text { Canister }\end{array}$ & Rp.109.000 & $\begin{array}{l}\text { Twin Tulipware Food } \\
\text { Container Medium }\end{array}$ & Rp. 89.000 \\
\hline \multicolumn{3}{|c|}{} \\
\hline
\end{tabular}

Berdasarkan tabel di atas dapat dilihat bahwa produk Tupperware memiliki harga yang bervariasi tergantung dari ukuran produk tersebut. Jika dibandingkan dengan pesaingnya, berdasarkan ukuran yang relatif sama maka produk Tupperware memiliki harga yang lebih tinggi. Hal ini tentu saja dapat mempengaruhi keputusan pembelian karena ada pesaing yang memliki harga lebih rendah. Harga yang mahal jika diimbangi dengan kualitas produk yang bagus tentu juga akan menjadi pertimbangan bagi konsumen untuk memutuskan pembelian.

Dalam memahami perilaku konsumen, terdapat banyak faktor yang mempengaruhi seseorang dalam mengambil keputusan pembelian suatu produk. Perilaku pembelian konsumen seringkali diawali dan dipengaruhi oleh banyaknya rangsangan (stimulus) dari luar dirinya, baik berupa rangsangan pemasaran maupun rangsangan dari lingkungan yang lain. Rangsangan tersebut kemudian diproses dalam diri, sesuai dengan karakteristik pribadinya, sebelum akhirnya diambil keputusan pembelian. Karakteristik pribadi konsumen yang dipergunakan untuk memproses rangsangan tersebut sangat komplek, salah satunya adalah motivasi konsumen untuk membeli. Menurut Kotler and Keller (2008) berpendapat keputusan pembelian adalah tahapan dalam proses pengambilan keputusan konsumen dimana konsumen benar-benar akan membeli. Keputusan pembelian konsumen kerap kali dipengaruhi oleh perilaku konsumen. Pengambilan keputusan dalam membeli suatu produk tentunya berbeda karena berbagai perbedaan yang terdapat pada produk dengan jenis yang sama tapi merek dan spesifikasi produk yang umumnya berbeda. Keputusan penjualan tentu saja berkaitan dengan berapa banyak suatu produk dapat terjual. Berikut ini merupakan data penjualan produk Tupperware: 


\begin{tabular}{|c|c|}
\hline \multicolumn{2}{|c|}{$\begin{array}{l}\text { Tabel 2. Data Penjualan Tupperware Pada } \\
\text { PT. Hasta Husnul Khotimah Tangerang } 2017\end{array}$} \\
\hline Bulan & Tahun 2017 \\
\hline Januari & 270 \\
\hline Februari & 250 \\
\hline Maret & 275 \\
\hline April & 250 \\
\hline Mei & 255 \\
\hline Juni & 285 \\
\hline Juli & 240 \\
\hline Agustus & 290 \\
\hline Sepetember & 250 \\
\hline Oktober & 354 \\
\hline November & 220 \\
\hline Desember & 235 \\
\hline Jumlah & 3.174 \\
\hline & ta Husnul Khotim \\
\hline
\end{tabular}

Bedasarkan tabel di atas menunjukan bahwa penjualan Tupperware pada tahun 2017 bersifat fluktuatif. Penjualan tertinggi pada bulan Oktober sebanyak 354 unit, tetapi pada dua dua bulan terakhir mengalami penurunan penjualan di bulan November sebanyak 220 unit, dan penjualan bulan Desember sebanyak 235 unit. Data tersebut menunjukan bahwa pembelian Tupperware pada setiap bulannya belum stabil,

Jika dilihat berdasarkan kualitas produk maka produk Tupperware memiliki keungulan daripada produk pesaingnya. Hal ini tentu saja berakibat pada mahalnya produk tersebut. Kedua aspek ini diduga kuat dapat mempengaruhi pembelian produk oleh konsumen. Berdasarkan uraian yang telah disampaikan di atas, muncul masalah apakah kualitas produk dan harga berpengaruh terhadap keputusan pembelian Tupperware.

\section{METODE}

\section{Jenis Penelitian}

Jenis penelitian ini adalah assosiatif. Menurut Sugiyono (2016: 21), "Penelitian asosiatif merupakan penelitian yang bertujuan untuk mengetahui hubungan dua variabel atau lebih. Dalam penelitian ini maka akan dapat dibangun suatu teori yang dapat berfungsi untuk menjelaskan, meramalkan dan mengontrol suatu gejala". Lebih lanjut Sugiyono (2012: 44) menjelaskan "Dengan penelitian asosiatif maka dapat dibangun suatu teori yang berfungsi untuk menjelaskan, meramalkan dan mengontrol suatu gejala". Penelitian ini bertujuan untuk menganalisa hubungan atau tingkat pengaruh variabel bebas (kualitas produk dan harga) terhadap variael terikat (keputusan pembelian).

\section{Populasi}

Populasi adalah wilayah generalisasi yang terdiri atas obyek/subyek yang mempunyai kuantitas dan karateristik tertentu yang di tetapkan oleh penelitian untuk dipelajari dan kemudian ditarik kesimpulannya (Sugiyono 2014). Jadi populasi bukan hanya orang, tetapi juga obyek dan benda-benda alam yang lainnya. Populasi juga bukan hanya sekedar jumah yang ada pada objek/ subyek yang dipelajari, tetapi meliputi seluruh karateristik/sifat yang dimiliki oleh subjek atau objek itu. Dalam penelitian ini yang dijadikan populasi adalah ibu-ibu rumah tangga yang pernah menggunakan produk Tupperware yaitu sebanyak 60 orang.

\section{Sampel}

Sampel adalah bagian dari jumlah dan berkarateristik yang dimiliki oleh populasi tersebut (Sugiyono 2012:81) sedangkan menurut Arikunto (2013: 174) berpendapat bahwa sampel adalah sebagian atau wakil populasi yang diteliti. Penelitian ini mengambil teknik pengambilan sampel berfokus pada teknik Sampling Jenuh. Menurut Sugiyono (2010:12) "Sampling Jenuh adalah teknik penentuan sampel bila semua anggota populasi digunakan sebagai sampel. Adapun sampal penelitian ini sebanyak 60 orang.

\section{Analisis Data dan Uji Hipotesis}

1. Rancangan Analisis
a. Uji Validitas
b. Uji Reliabilitas

2. Uji Asumsi Klasik
a. Uji Normalitas
b. Uji Multikolinearitas
c. Uji Autokoreasi
d. Uji Heteroskedastisi

3. Uji Regresi Linier Sederhana dan Regresi 
Linier Berganda

a. Uji Regresi Linier Sederhana (Uji Statistik (t))

b. Uji Regresi Linier Berganda (Uji F, serentak/simultan) dengan analisis Analysis of varian (ANOVA)

c. Uji Koefesien Diterminasi

\section{HASIL dan PEMBAHASAN Kualitas Produk}

Menurut Kotler dan Amstrong (2012:283), "kualitas produk adalah kemampuan sebuah produk dalam memperagakan fungsiya, hal ini termasuk keseluruhan durabilitas, reliabilitas, ketepatan, kemudahan pengoperasian, dan reparasi produk, juga atribut produk lainnya. Perusahaan harus benar-benar memahami apa yang dibutuhkan konsumen atas suatu produk yang akan dihasilkan".

Menurut Kotler and Armstrong (2012:283) arti dari kualitas produk adalah "theeability ofaa product to perform itssfunctions, it includes the product's overallddurability, reliability, precision, easeeof operationnand repair, andootherrvalued attributes" yang artinya kemampuan sebuah produk dalam memperagakan fungsinya, hal itu termasuk keseluruhan durabilitas, reliabilitas, ketepatan, kemudahan pengoperasian dan reparasi produk juga atribut produk lainnya. Kualitas produk (product quality) adalah salah satu sarana positioning utama pemasar. Tjiptono (2015:105) mengemukakan bahwa: "Definisi konvensional dari kualitas adalah sebagai gambaran langsung dari suatu produk seperti performasi, keandalan, mudah dalam penggunaan estetika dan sebagainya. Dalam definisi stratejik, kualitas adalah segala sesuatu yang mampu memenuhi keinginan atau kebutuhan pelanggan (meeting the needs of customer)".

\section{Indikator Kualitas Produk}

Menurut Tjiptono (2011) indikator yang digunakan untuk mengukur kualitas produk antara lain:

1. Performance (kinerja), berhubungan dengan karakteristik operasi dasar dari sebuah pro- duk.

2. Durability (daya tahan), yang berarti berapa lama atau umur produk yang bersangkutan bertahan sebelum produk tersebut harus diganti. Semakin besar frekuensi pemakaian konsumen terhadap produk maka semakin besar pula daya tahan produk.

3. Conformance to Specifications (kesesuaian dengan spesifikasi), yaitu sejauh mana karakteristik operasi dasar dari sebuah produk memenuhi spesifikasi tertentu dari konsumen atau tidak ditemukannya cacat pada produk.

4. Features (fitur), adalah karakteristik produk yang dirancang untuk menyempurnakan fungsi produk atau menambah ketertarikan konsumen terhadap produk.

5. Reliabilty (reliabilitas), adalah probabilitas bahwa produk akan bekerja dengan memuaskan atau tidak dalam periode waktu tertentu. Semakin kecil kemungkinan terjadinya kerusakan maka produk tersebut dapat diandalkan.

6. Aesthetics (estetika), berhubungan dengan bagaimana penampilan produk bisa dilihat dari tampak, rasa, bau, dan bentuk dari produk.

\section{Harga}

Harga sebuah produk atau jasa merupakan faktor penentu dalam permintaan pasar. Harga merupakan hal yang sangat penting yang diperhatikan oleh konsumen dalam membeli produk atau jasa. Menurut Swastha (2010: 147), "Harga adalah jumlah uang (ditambah beberapa barang kalau mungkin) yang dibutuhkan untuk mendapatkan sejumlah kombinasi dari barang beserta pelayanannya". Menurut Kotler dan Keller yang dialih bahasakan oleh Bob Sabran (2009: 67), "harga adalah salah satu elemen bauran pemasaran yang menghasilkan pendapatan, elemen lain menghasilkan biaya. Harga merupakan elemen termudah dalam program pemasaran untuk disesuaikan, fitur produk, saluran, dan bahkan komunikasi membutuhkan banyak waktu". Sedangkan menurut Tjiptono (2012: 151) "harga adalah satuan moneter atau ukuran lainnya (termasuk barang dan jasa lainnya) yang ditu- 
karkan agar memperoleh hak kepemilikan atau pengunaan suatu barang atau jasa. Pengertian ini sejalan dengan konsep pertukaran (exchange) dalam pemasaran".

\section{Keputusan Pembelian}

Pemahaman mengenai keputusan pembelian konsumen meliputi bagaimana individu, kelompok atau organisasi memilih, membeli, menggunakan dan tidak menggunakan barang dan jasa. Memahami konsumen tidaklah mudah karena setiap konsumen memutuskan pembelian tertentu yang berbeda-beda dan sangat bervariasi. Menurut Fandy Tjiptono (2014: 21) "keputusan pembelian adalah sebuah proses dimana konsumen mengenal masalahnya, mencari informasi mengenai produk atau merek tertentu dan mengevaluasi seberapa baik masing-masing alternatif tersebut dapat memecahkan masalahnya, yang kemudian mengarah kepada keputusan pembelian".

\section{Proses Keputusan Pembelian}

Menurut Kotler dan Keller (2014: 176) "Proses keputusan pembelian merupakan proses dimana konsumen melewati lima tahap, yaitu pengenalan masalah, pencarian informasi, evaluasi alternatif, keputusan pembelian, dan perilaku pasca pembelian, yang dimulai jauh sebelum pembelian aktual dilakukan dan memiliki dampak yang lama setelah itu."

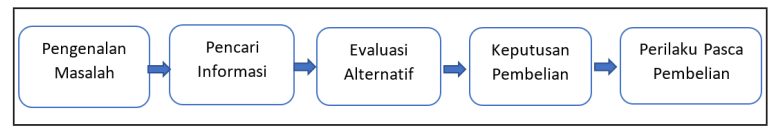

Gambar 1. Proses Keputusan Pembelian

\section{Hasil}

\section{Uji Validitas}

Untuk menguji validitas setiap instrumen, rumus yang dipakai adalah koefisein korelasi product moment dengan taraf signifikansi $\alpha=0,1$ atau (10\%), artinya tingkat kepercayaan pengujiannya adalah $90 \%$. Kriteria pengujian validitas jika nilai $\mathrm{r}_{\text {hitung }}>\mathrm{r}_{\text {tabel }}$, maka butir pernyataan dikatakan valid, jika nilai $\mathrm{r}_{\text {hitung }}<\mathrm{r}_{\text {tabel }}$ maka butir pernyataan dikatakan tidak valid.

\begin{tabular}{|c|c|c|c|}
\hline \multicolumn{4}{|c|}{ Tabel 3. Uji Validitas Kualitas Produk ( $\mathbf{X}^{\prime}$ ) } \\
\hline Item Pernyataan & $\mathbf{r}_{\text {hitung }}$ & $\mathbf{r}_{\text {tabel }}$ & Keputusan \\
\hline 1 & 0,369 & 0,214 & Valid \\
\hline 2 & 0,525 & 0,214 & Valid \\
\hline 3 & 0,405 & 0,214 & Valid \\
\hline 4 & 0,334 & 0,214 & Valid \\
\hline 5 & 0,513 & 0,214 & Valid \\
\hline 6 & 0,452 & 0,214 & Valid \\
\hline 7 & 0,587 & 0,214 & Valid \\
\hline 8 & 0,601 & 0,214 & Valid \\
\hline 9 & 0,571 & 0,214 & Valid \\
\hline 10 & 0,538 & 0,214 & Valid \\
\hline \multicolumn{4}{|l}{} \\
\hline
\end{tabular}

\begin{tabular}{|c|c|c|c|}
\hline \multicolumn{5}{|c|}{ Tabel 4. Uji Validitas Harga (X') } \\
\hline Item Pernyataan & $\mathbf{r}_{\text {hitung }}$ & $\mathbf{r}_{\text {tabel }}$ & Keputusan \\
\hline 1 & 0,484 & 0,214 & Valid \\
\hline 2 & 0,517 & 0,214 & Valid \\
\hline 3 & 0,421 & 0,214 & Valid \\
\hline 4 & 0,448 & 0,214 & Valid \\
\hline 5 & 0,469 & 0,214 & Valid \\
\hline 6 & 0,495 & 0,214 & Valid \\
\hline 7 & 0,665 & 0,214 & Valid \\
\hline 8 & 0,612 & 0,214 & Valid \\
\hline 9 & 0,573 & 0,214 & Valid \\
\hline 10 & 0,517 & 0,214 & Valid \\
\hline \multicolumn{4}{|l}{} \\
\hline
\end{tabular}

\begin{tabular}{|c|c|c|c|}
\hline \multicolumn{4}{|c|}{ Tabel 5. Uji Validitas Keputusan Pembelian ( $\mathbf{Y}$ ) } \\
\hline Item Pernyataan & $\mathbf{r}_{\text {hitung }}$ & $\mathbf{r}_{\text {tbeal }}$ & Keputusan \\
\hline 1 & 0,524 & 0,214 & Valid \\
\hline 2 & 0,546 & 0,214 & Valid \\
\hline 3 & 0,256 & 0,214 & Valid \\
\hline 4 & 0,649 & 0,214 & Valid \\
\hline 5 & 0,432 & 0,214 & Valid \\
\hline 6 & 0,556 & 0,214 & Valid \\
\hline 7 & 0,637 & 0,214 & Valid \\
\hline 8 & 0,516 & 0,214 & Valid \\
\hline 9 & 0,396 & 0,214 & Valid \\
\hline 10 & 0,534 & 0,214 & Valid \\
\hline \multicolumn{4}{|l}{} \\
\hline
\end{tabular}

\section{Uji Reliabilitas}

Uji validitas menggunakan Alpha Cronbach dilakukan dengan membandingkan antara nilai $\mathrm{r}_{\text {hitung }}$ dengan nilai $\mathrm{r}_{\text {tabel }}$ Nilai $\mathrm{r}_{\text {tabel }}$ dalam penelitian ini dengan 60 responden adalah 0,214. dengan taraf signifikansi $\alpha=0,1(10 \%)$ dengan tingkat kepercayaan pengujiannya adalah $90 \%$. Adapun kriteria uji reliabilitas adalah jika nilai $\mathrm{r}_{\text {hitung }}>$ $\mathrm{r}_{\text {tabel }}$ dan nilai $\mathrm{r}$ positif, maka butir pernyataan 
dikatakan reliabel, jika nilai $\mathrm{r}_{\text {hitung }}<\mathrm{r}_{\text {tabel }}$ dan nilai $r$ negatif, maka butir pernyataan dikatakan tidak reliabel.

\begin{tabular}{|c|c|c|c|}
\hline Variabel & $r_{\text {hitung }}$ & $r_{\text {tabel }}$ & Keputusan \\
\hline Kualitas Produk (X') & 0.632 & 0.214 & Reliabel \\
\hline Harga $\left(X^{2}\right)$ & 0.694 & 0.214 & Reliabel \\
\hline Keputusan Pembelian (Y) & 0.733 & 0.214 & Reliabel \\
\hline \multicolumn{4}{|c|}{ Sumber: Data diolah } \\
\hline
\end{tabular}

\section{Uji Normalitas}

Uji normalitas dilakukan dengan One-Sample Kolmogorov-Smirnov Test. Jika didapat nilai signifikan >0,05, maka dapat disimpulkan bahwa data berdistribusi normal secara multivariate.

\begin{tabular}{|c|c|c|}
\hline \multicolumn{3}{|c|}{ Tabel 7. Hasil Uji Statistik } \\
\hline \multicolumn{3}{|c|}{ One-Sample Kolmogorov-Smirnov Test } \\
\hline & & $\begin{array}{l}\text { Unstandardized } \\
\text { Residual }\end{array}$ \\
\hline \multicolumn{2}{|l|}{$\mathrm{N}$} & 60 \\
\hline \multirow[t]{2}{*}{ Normal Parametersa,b } & Mean &, 0000000 \\
\hline & Std. Deviation & 2,94476939 \\
\hline \multirow[t]{3}{*}{ Most Extreme Differences } & Absolute & .092 \\
\hline & Positive & .092 \\
\hline & Negative &,- 077 \\
\hline \multicolumn{2}{|l|}{ Test Statistic } & .710 \\
\hline \multicolumn{2}{|l|}{ Asymp. Sig. (2-tailed) } & ,694 \\
\hline \multicolumn{3}{|c|}{$\begin{array}{l}\text { a. Test distribution is Normal. } \\
\text { b. Calculated from data. }\end{array}$} \\
\hline \multicolumn{3}{|r|}{ Sumber: Data diolah } \\
\hline
\end{tabular}

Berdasarkan tabel di atas diketahui hasil Kolmogrov-Smirnov menunjukkan angka 0,710 dengan tingkat signifikansi yang berarti berada di atas 0.05 dengan demikian dapat disimpulkan bahwa variabel telah terdistribusi secara normal.

\section{Uji Multikolinearitas}

Uji multikolinearitas dapat dilakukan dengan melihat nilai Tolerance Value dan Variance Inflation Factor (VIF). Adapun sebagai prasyarat adalah jika nilai VIF > 10 dan nilai tolerance value $>1$ maka terjadi gejala multikolinearitas, jika nilai VIF $<10$ dan nilai tolerance value $<1$ maka tidak terjadi gejala multikolinearitas.

\begin{tabular}{|c|c|c|c|c|c|c|c|c|}
\hline \multicolumn{9}{|c|}{ Coefficients $^{a}$} \\
\hline \multirow{2}{*}{\multicolumn{2}{|c|}{ Model }} & \multicolumn{2}{|c|}{$\begin{array}{l}\text { Unstandardized } \\
\text { Coefficients }\end{array}$} & \multirow{2}{*}{$\begin{array}{c}\text { Standard- } \\
\text { ized Coef- } \\
\text { ficients }\end{array}$} & \multirow{2}{*}{$t$} & \multirow{2}{*}{ Sig. } & \multicolumn{2}{|c|}{$\begin{array}{l}\text { Collinearity } \\
\text { Statistics }\end{array}$} \\
\hline & & B & $\begin{array}{l}\text { Std. } \\
\text { Error }\end{array}$ & & & & $\begin{array}{l}\text { Toler- } \\
\text { ance }\end{array}$ & VIF \\
\hline \multirow{3}{*}{1} & (Constant) & 11,685 & 4,166 & & 2,805 & ,007 & & \\
\hline & Kualitas Produk &, 250 &, 123 &, 246 & 2,036 &, 046 & ,658 & 1,521 \\
\hline & Harga &, 492 & 120 &, 497 & 4,112 &, 000 &, 658 & 1,521 \\
\hline
\end{tabular}

Berdasarkan tabel di atas diperoleh nilai Variance Inflation Factor (VIF) masing-masing variabel bebas memiliki nilai toleransi $<1$ dan nilai VIF $<10$, dengan demikian model regresi ini tidak ada multikolinearitas.

\section{Uji Autokorelasi}

Untuk mengetahui adanya autokorelasi dilakukan pengujian Durbin-Watson (DW) dengan membandingkan nilai Durbin-Watson dengan kriteria atau pedoman dalam interpretasi DurbinWatson (DW test)

\begin{tabular}{|c|c|c|c|c|c|}
\hline \multicolumn{6}{|c|}{ Tabel 9. Hasil Uji Autokorelasi } \\
\hline \multicolumn{6}{|c|}{ Model Summaryb } \\
\hline Model & $\mathbf{R}$ & R Square & $\begin{array}{l}\text { Adjusted } \\
\text { R Square }\end{array}$ & $\begin{array}{c}\text { Std. Error } \\
\text { of the Estimate }\end{array}$ & $\begin{array}{l}\text { Durbin- } \\
\text { Watson }\end{array}$ \\
\hline 1 & $.672^{\mathrm{a}}$ & .451 &, 432 & 2,93531 & 1,912 \\
\hline \multicolumn{6}{|c|}{ a. Predictors: (Constant), Harga, Kualitas Produk } \\
\hline \multicolumn{6}{|c|}{ b. Dependent Variable: Keputusan Pembelian } \\
\hline \multicolumn{6}{|c|}{ Sumber: Data diola } \\
\hline
\end{tabular}

Berdasarkan hasil pengujian pada tabel di atas, model regresi ini tidak ada autokorelasi, hal ini dibuktikan dengan nilai Durbin-Watson sebesar 1,912 yang berada diantara 1,550 - 2.460.

\section{Uji Heteroskedastisitas}

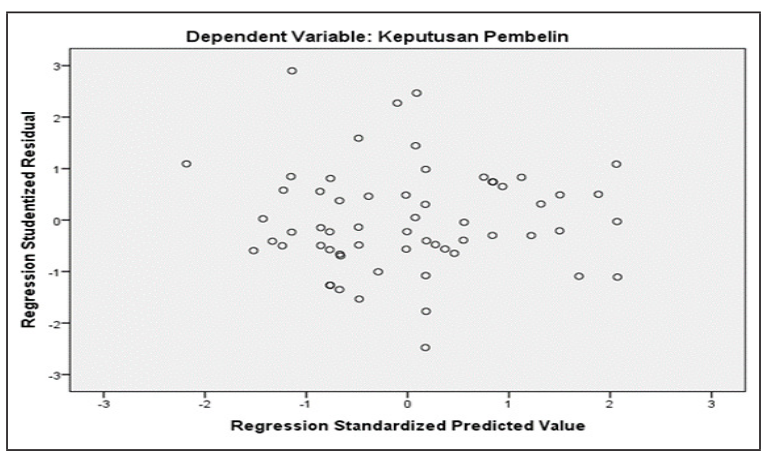

Gambar 2. Grafik Scatter Plot Hasil Uji Heteroskedastisitas 
Berdasarkan hasil gambar di atas, titik-titik pada grafik scatterplot tidak mempunyai pola penyebaran yang jelas atau tidak membentuk polapola tertentu dan titik-titik tersebut menyebar di atas dan di bawah angka 0 pada sumbu Y, dengan demikian hal ini menunjukkan bahwa tidak terdapat gangguan heteroskedastisitas pada model regresi sehingga model regresi ini layak dipakai.

\section{Uji Regresi Linier Sederhana (Uji t parsial)}

Untuk pengujian hipotesis variabel kualitas produk $\left(\mathrm{X}^{1}\right)$ dan harga $\left(\mathrm{X}^{2}\right)$ terhadap keputusan pembelian (Y) dilakukan dengan uji statistik $t$ (uji secara parsial). Dalam penelitian ini digunakan kriteria signifikansi $10 \%(0,1)$ dengan membandingkan $\mathrm{t}_{\text {hitung }}$ dengan $\mathrm{t}_{\text {tabel }}$ yaitu sebagai berikut:

a) Jika $\mathrm{t}_{\text {hitung }}<\mathrm{t}_{\text {tabel }}$ : berarti $\mathrm{H}_{0}$ diterima dan $\mathrm{H}_{1}$ ditolak

b) Jika $\mathrm{t}_{\text {hitung }}>\mathrm{t}_{\text {tabel }}$ : berarti $\mathrm{H}_{0}$ ditolak dan $\mathrm{H}_{1}$ diterima

Adapun untuk menentukan besarnya $t$ tabel dicari dengan menggunakan rumus berikut ini :

$$
\begin{array}{ll}
\mathrm{t}_{\text {tabel }} & =\mathrm{t} \alpha \cdot \mathrm{df} \text { (Taraf Alpha } \mathrm{x} \text { Degree of Freedom) } \\
\mathrm{a} & =\text { tarif nyata } 10 \% \\
\mathrm{df} & =(\mathrm{n}-2), \text { maka diperoleh }(60-2)=58 \\
\mathrm{t}_{\text {tabel }} & =1,296
\end{array}
$$

\begin{tabular}{|c|c|c|c|c|c|c|}
\hline \multicolumn{7}{|c|}{ Coefficients $^{a}$} \\
\hline \multirow{2}{*}{\multicolumn{2}{|c|}{ Model }} & \multicolumn{2}{|c|}{$\begin{array}{l}\text { Unstandardized } \\
\text { Coefficients }\end{array}$} & \multicolumn{3}{|c|}{ Standardized Coefficients } \\
\hline & & \multirow{2}{*}{$\begin{array}{l}\text { B } \\
19,389\end{array}$} & \multirow{2}{*}{$\begin{array}{c}\begin{array}{c}\text { Std. } \\
\text { Error }\end{array} \\
4,201 \\
\end{array}$} & \multirow[t]{2}{*}{ Beta } & \multirow{2}{*}{$\begin{array}{l}\mathrm{t} \\
4,616\end{array}$} & \multirow{2}{*}{$\begin{array}{l}\text { Sig. } \\
, 000\end{array}$} \\
\hline & (Constant) & & & & & \\
\hline I & Kualitas Produk & .547 & .113 &, 537 & 4,852 & ,000 \\
\hline \multicolumn{7}{|c|}{ a. Dependent Variable: Keputusan Pembelian } \\
\hline & & & & & \multicolumn{2}{|c|}{ Sumber: Data diolah } \\
\hline
\end{tabular}

Tabel 10. Hasil Uji t Variabel Kualitas Produk (X')

Berdasarkan tabel di atas diperoleh nilai $\mathrm{t}_{\text {hitung }}$ $>\mathrm{t}_{\text {tabel }}(4,852>1,296)$, hal itu juga dibuktikan dengan signifikansi $0,000<0,1$. Dengan demikian maka $\mathrm{H}_{0}$ ditolak dan $\mathrm{H}_{1}$ diterima, hal ini menunjukkan bahwa terdapat pengaruh yang

\begin{tabular}{|c|c|c|c|c|c|c|}
\hline \multicolumn{7}{|c|}{$\begin{array}{c}\text { Tabel 11. Hasil Uji t Variabel Harga (X } \\
\text { Coefficients }^{\mathrm{a}}\end{array}$} \\
\hline \multirow{2}{*}{\multicolumn{2}{|c|}{ Model }} & \multicolumn{2}{|c|}{$\begin{array}{l}\text { Unstandardized } \\
\text { Coefficients }\end{array}$} & \multicolumn{3}{|c|}{ Standardized Coefficients } \\
\hline & & B & $\begin{array}{l}\text { Std. } \\
\text { Error }\end{array}$ & Beta & $\mathrm{t}$ & Sig. \\
\hline \multirow{2}{*}{1} & (Constant) & 15,564 & 3,804 & & 4,092 &, 000 \\
\hline & Harga & .634 & , 100 & .642 & 6,370 &, 000 \\
\hline \multicolumn{7}{|c|}{ a. Dependent Variable: Keputusan Pembelian } \\
\hline & & & & & \multicolumn{2}{|c|}{ Sumber: Data diolah } \\
\hline
\end{tabular}
positif dan signifikan secara parsial antara kualitas produk terhadap keputusan pembelian pada produk Tupperware.
Berdasarkan tabel di atas diperoleh nilai $t_{\text {hitung }}$ $>\mathrm{t}_{\text {tabel }}(6,370>1.296)$, hal itu juga dibuktikan dengan signifikansi $0,000<0,1$. Dengan demikian maka $\mathrm{H}_{0}$ ditolak dan $\mathrm{H}_{1}$ diterima, hal ini menunjukkan bahwa terdapat pengaruh yang positif dan signifikan secara parsial antara harga terhadap keputusan pembelian pada produk Tupperware.

\section{Uji Regresi Linier Berganda (Uji F simultan)}

Untuk pengujian pengaruh variabel kualitas produk, harga dan keputusan pembelian secara simultan terhadap kepuasan pelanggan pada produk Tupperware, dilakukan dengan uji statistik F (uji simultan) dengan signifikansi 10\% dan membandingkan antara nilai $\mathrm{F}_{\text {hitung }}$ dengan $\mathrm{F}$ tabel dengan ketentuan sebagai berikut:

a) Jika $\mathrm{F}_{\text {hitung }}<\mathrm{F}_{\text {tabel }}$ : berarti $\mathrm{H}_{0}$ diterima dan $\mathrm{H}_{1}$ ditolak

b) Jika $\mathrm{F}_{\text {hitung }}>\mathrm{F}_{\text {tabel }}$ : berarti $\mathrm{H}_{0}$ ditolak dan $\mathrm{H}_{1}$ diterima

\begin{tabular}{|c|c|c|c|c|c|c|}
\hline \multicolumn{7}{|c|}{ Tabel 12. Hasil Uji F Simultan } \\
\hline \multicolumn{7}{|c|}{ ANOVA $^{\mathrm{a}}$} \\
\hline \multicolumn{2}{|c|}{ Model } & $\begin{array}{l}\text { Sum of } \\
\text { Squares }\end{array}$ & Df & $\begin{array}{l}\text { Mean } \\
\text { Square }\end{array}$ & $\mathrm{F}$ & Sig. \\
\hline \multirow{3}{*}{1} & Regression & 404,220 & 2 & 202,110 & 23,457 &, $000^{\mathrm{b}}$ \\
\hline & Residual & 491,113 & 57 & 8,616 & & \\
\hline & Total & 895,333 & 59 & & & \\
\hline \multicolumn{7}{|c|}{ a. Dependent Variable: Keputusan Pembelian } \\
\hline \multicolumn{7}{|c|}{ b. Predictors: (Constant), Harga, Kualitas Produk } \\
\hline & & & & & \multicolumn{2}{|c|}{ Sumber: Data diolala } \\
\hline
\end{tabular}

Untuk menentukan besarnya $F_{\text {tabel }}$ dicari dengan ketentuan $\mathrm{df}=(\mathrm{n}-\mathrm{k}-1)$, maka diperoleh $(60-3-1)=56$, jadi $\mathrm{F}_{\text {tabel }}=2,800$

Berdasarkan tabel di atas, diperoleh nilai $\mathrm{F}_{\text {hitung }}$ lebih besar dari $\mathrm{F}_{\text {tabel }}$ atau $(23.457>2.800)$, 
hal tersebut juga diperkuat dengan signifikansi $0,000<0,1$. Dengan demikian $\mathrm{H}_{0}$ ditolak dan $\mathrm{H}_{1}$ diterima. Artinya terdapat pengaruh positif dan signifikan secara simultan antara kualitas produk dan harga terhadap keputusan pembelian pada produk Tupperware.

\section{Uji Koefesien Diterminasi}

Koesfisien Determinasi (Kd) dipergunakan untuk mengetahui seberapa besar tingkat hubungan atau pengaruh antara variabel kualitas produk $\left(\mathrm{X}^{1}\right)$ dan harga $\left(\mathrm{X}^{2}\right)$ terhadap variabel keputusan pembelian $(\mathrm{Y})$.

\begin{tabular}{|c|c|c|c|c|c|}
\hline \multicolumn{6}{|c|}{$\begin{array}{l}\text { Tabel 13. Koefiisien Determinasi Variabel } \\
\text { Kualitas Produk ( } X^{1} \text { ) dan Harga ( } X^{2} \text { ) }\end{array}$} \\
\hline \multicolumn{6}{|c|}{ Model Summaryb } \\
\hline Model & $\mathbf{R}$ & R Square & $\begin{array}{l}\text { Adjusted } \\
\text { R Square }\end{array}$ & $\begin{array}{c}\text { Std. Error } \\
\text { of the Estimate }\end{array}$ & $\begin{array}{l}\text { Durbin- } \\
\text { Watson }\end{array}$ \\
\hline 1 & $.672^{\mathrm{a}}$ & .451 & .432 & 2.935 & 1.912 \\
\hline \multicolumn{6}{|c|}{ a. Predictors: (Constant), Harga (X'), Kualitas Produk (X') } \\
\hline \multicolumn{6}{|c|}{ b. Dependent Variable: Keputusan Pembelian (Y) } \\
\hline \multicolumn{6}{|c|}{ Sumber: Data diolah } \\
\hline
\end{tabular}

Berdasarkan tabel di atas, diperoleh nilai $R$-square (koefisien determinasi) sebesar 0,451 maka dapat disimpulkan bahwa variabel kualitas produk $\left(\mathrm{X}^{1}\right)$ dan harga $\left(\mathrm{X}^{2}\right)$ berpengaruh terhadap variabel keputusan pembelian (Y) pada produk Tupperware sebesar $45,1 \%$ sedangkan sisanya $54,9 \%$ dipengaruhi oleh variabel lain yang tidak diteliti dalam penelitian ini.

\section{Pembahasan}

Berdasarkan hasil penelitian yang didapatkan, maka dapat diungkapkan pembahasan pengaruh kualitas produk dan harga terhadap keputusan pembelian sebagai berikut:

1. Pengaruh Kualitas Produk Terhadap Keputusan Pembelian

Berdasarkan hasil statistik dapat diketahui bahwa pengaruh kualitas produk terhadap keputusan pembelian sebesar 0,246 maka dapat disimpulkan bahwa variabel kualitas produk $\left(\mathrm{X}^{1}\right)$ berpengaruh terhadap variabel keputusan pembelian (Y) sebesar 24,6\% sedangkan sisanya $75,4 \%$ dipengaruhi oleh variable lain yang tidak diteliti dalam penelitian ini. Hal ini menunjukkan bahwa kualitas produk yang tinggi akan meningkatkan keputusan pembelian. Berdasarkan nilai $t_{\text {hitung }}$ $>\mathrm{t}_{\text {tabel }}(4,852>1.296)$, hal itu juga dibuktikan dengan signifikansi $0,000<0,1$. Dengan demikian maka $\mathrm{H}_{0}$ ditolakdan $\mathrm{H}_{1}$ diterima, hal ini menunjukkan bahwa terdapat pengaruh yang positif dan signifikan secara parsial antara kualitas produk terhadap Keputusan pembelian pada produk Tupperware. Hasil penelitian ini konsisten dengan penelitian Mariana, (2015) dimana dalam penelitiannya menghasilkan kesimpulan bahwa produk terbukti berpengaruh positif dan signifikan terhadap keputusan pembelian, dan ini sesuai dengan pendapat Kotler dan Armstrong (2012) dimana "Kualitas produk mencerminkan semua dimensi penawaran produk yang menghasilkan manfaat (benefits) bagi pelanggan. Kualitas suatu produk baik berupa barang atau jasa ditentukan melalui dimensinya".

2. Pengaruh Harga terhadap Keputusan Pembelian

Berdasarkan hasil statistik dapat diketahui bahwa pengaruh harga $\left(\mathrm{X}^{2}\right)$ terhadap keputusan pembelian (Y) Berdasarkan diperoleh nilai sebesar 0,497 maka dapat disimpulkan bahwa variabel harga $\left(\mathrm{X}^{2}\right)$ berpengaruh terhadap variabel keputusan pembelian (Y) sebesar 49,7\% sedangkan sisanya 50,3\% dipengaruhi oleh faktor ain. Hal ini menunjukkan bahwa harga yang tinggi akan meningkatkan keputusan pembelian. Berdasarkan tabel di atas diperoleh nilai $\mathrm{t}_{\text {hitung }}>\mathrm{t}_{\text {tabel }}$ (6,370 > 1.296), hal itu juga dibuktikan dengan signifikansi $0,000<0,1$. Dengan demikian maka $\mathrm{H}_{0}$ ditolak dan $\mathrm{H}_{1}$ diterima, hal ini menunjukkan bahwa terdapat pengaruh yang positif dan signifikan antara harga terhadap keputusan pembelian pada produk Tupperware. Hasil penelitian ini konsisten dengan penelitian Christy Jacklin Gerung dkk, (2017) dimana dalam penelitiannya menghasilkan kesimpulan bahwa produk terbukti berpengaruh positif dan signifikan terhadap keputusan pembelian, dan ini sesuai dengan pendapat Tjiptono (2012) 
"harga adalah satuan moneter atau ukuran lainnya (termasuk barang dan jasa lainnya) yang ditukarkan agar memperoleh hak kepemilikan atau pengunaan suatu barang atau jasa ditentukan dengan dimensinya.

3. Pengaruh Kualitas Produk dan Harga Terhadap Keputusan Pembelian

Berdasarkan hasil penelitian, menunjukkan bahwa kualitas produk $\left(\mathrm{X}^{1}\right)$ dan harga $\left(\mathrm{X}^{2}\right)$ berpengaruh positif terhadap keputusan pembelian pada produk Tupperware, berdasarkan hasil perhitungan regresi dapat diperoleh persamaan regresinya $\mathrm{Y}=11,685+$ $0,250 X^{1}+0,492 X^{2}$. Hasil analisis regresi ini menunjukkan koefisien dari masing-masing variabel bertanda positif dan memiliki hubungan yang searah, artinya semakin baik kualitas produk dan harga maka akan semakin baik pula keputusan pembelian pada produk Tupperware. Sebaliknya, semakin rendah kualitas produk dan harga maka akan semakin rendah pula keputusan pembelian pada produk Tupperware. Kontribusi pengaruh kualitas produk dan harga adalah sebesar 0,404 maka dapat disimpulkan bahwa variabel kualitas produk $\left(\mathrm{X}^{1}\right)$ dan harga $\left(\mathrm{X}^{2}\right)$ berpengaruh terhadap variabel keputusan pembelian (Y) pada produk Tupperware sebesar $40,4 \%$ sedangkan sisanya $59,6 \%$ dipengaruhi oleh faktor lain. Dari pengujian hipotesis menggunakan uji statistik, diperoleh nilai $\mathrm{F}_{\text {hitung }}$ lebih besar dari $\mathrm{F}_{\text {tabel }}$ atau $(23,457>2.770)$, hal tersebut juga diperkuat dengan signifikansi $0,000<0,1$. Dengan demikian $\mathrm{H}_{0}$ ditolak dan $\mathrm{H}_{1}$ diterima. Artinya terdapat pengaruh positif dan signifikan secara simultan antara kualitas produk dan harga terhadap keputusan pembelian pada pada produk Tupperware. Hasil penelitian ini konsisten dengan penelitian Anugrah Janwar Tuwis, dkk (2016) dengan penelitiannya yang berkesimpulan bahwa terdapat pengaruh yang positif signifikan antara kualitas produk dan harga berpengaruh secara simultan sebesar 68,3\% terhadap keputusan pembelian. Pengujian hipotesis secara simultan diperoleh nilai sig sebesar 0.000 yang berarti kualitas produk dan harga berpengaruh positif dan signifikan terhadap keputusan pembelian

\section{SIMPULAN}

Berdasarkan hasil penelitian dan pembahasan, maka dapat ditarik kesimpulan sebagai berikut: Kualitas produk $\left(\mathrm{X}^{1}\right)$ berpengaruh terhadap keputusan pembelian (Y) sebesar 24,6\%. Hal ini menunjukkan bahwa kualitas produk yang tinggi akan meningkatkan keputusan pembelian. Dari pengujian hipotesis diperoleh $\mathrm{t}$ nilai $\mathrm{t}_{\text {hitung }}>\mathrm{t}_{\text {tabel }}$ $(4,852>1.296)$, hal itu juga dibuktikan dengan signifikansi $0,000<0,1$. Dengan demikian maka $\mathrm{H}_{0}$ ditolak dan $\mathrm{H}_{1}$ diterima, hal ini menunjukkan bahwa terdapat pengaruh yang positif dan signifikan secara parsial antara kualitas produk terhadap Keputusan pembelian. Harga $\left(\mathrm{X}^{2}\right)$ terhadap keputusan pembelian (Y) sebesar 49,7 \%. Hal ini menunjukkan bahwa harga yang tinggi akan meningkatkan keputusan pembelian. Dari pengujian hipotesis diperoleh $\mathrm{t}_{\text {hitung }}$ nilai $\mathrm{t}_{\text {hitung }}>\mathrm{t}_{\text {tabel }}$ $(6,370>1.296)$, hal itu juga dibuktikan dengan signifikansi $0,000<0,1$. Dengan demikian maka $\mathrm{H}_{0}$ ditolak dan $\mathrm{H}_{1}$ diterima, hal ini menunjukkan bahwa terdapat pengaruh yang positif dan signifikan secara parsial antara harga terhadap keputusan pembelian. Kualitas produk dan harga berpengaruh positif terhadap keputusan pembelian dengan persamaan regresi $Y=11,685+$ $0,250 \mathrm{X}^{1}+0,492 \mathrm{X}^{2}$. Semakin tinggi kualitas produk dan harga maka akan semakin meningkatkan keputusan pembelian. Demikian pula sebaliknya, jika kualitas produk dan harga rendah maka keputusan pembelian juga akan mengalami penurunan. Kontribusi pengaruh kualitas produk harga dan keputusan pembelian secara simultan adalah sebesar 40,4 \% sedangkan sisanya sebesar $59,6 \%$ dipengaruhi faktor lain. diperoleh nilai $\mathrm{F}_{\text {hitung }}$ lebih besar dari $\mathrm{F}_{\text {tabel }}$ atau $(23,457>2.800)$, hal tersebut juga diperkuat dengan signifikansi $0,000<0,1$. Dengan demikian $\mathrm{H}_{0}$ ditolak dan $\mathrm{H}_{1}$ diterima. Artinya terdapat pengaruh positif dan signifikan secara simultan antara kualitas produk dan harga terhadap keputusan pembelian 


\section{PENGHARGAAN}

Pada kesempatan kali ini penulis ingin mengucapkan terimakasih kepada semua yang terlibat baik secara langsung maupun tidak langsung yang tidak bisa penulis sebutkan satu persatu. Terimakasih atas saran, masukan, dan bantuan, semoga penelitian ini bisa bermanfaat bagi semua pihak.

\section{DAFTAR PUSTAKA}

Arikunto, S. (2013). Prosedur Penelitian: Suatu Pendekatan Praktik. Jakarta: Rineka Cipta.

Arseculeratne, D. and Yazdanifard R. (2014). How Green Marketing Can Create A Sustainable Competitive Advantage for A Business. International Business Research, Vol. 7, No. 1, pp 130-137.

Gerung, C. J., Sepang, J., \& Loindong, S. (2017). Pengaruh Kualitas Produk, Harga dan Promosi Terhadap Keputusan Pembelian Mobil Nissan $X$-Trail Pada PT Wahana Wirawan Manado. Jurnal EMBA. Vol.5 No.2 Juni 2017, Hal. $2221-2229$

Hasan, A. (2008). Marketing. Jakarta: MedPress.

Kotler, P. \& Armstrong, G. (2012). Prinsip-prinsip Pemasaran. Edisi 13. Jilid 1. Jakarta: Erlangga. Kotler, P. \& Keller. (2008). Manajemen Pemasaran. Edisi Ketiga Belas. Jilid 1. Jakarta: Erlangga.
Kotler, P. \& Keller. (2009). Manajemen Pemasaran, Edisi 13. Jilid 1. Alih Bahasa. Bob Sabran. Erlangga. Jakarta.

Mariana. (2015). Pengaruh Kualitas Produk dan Harga Terhadap Keputusan Pembelian Produk Pada Industri UKM Amplang UD. Sinar Rejeki di Samarinda. eJournal Ilmu Administrasi Bisnis, Vol. 3 No. 2: 388-402

Sugiyono. (2012). Metode Penelitian Kuantitatif Kualitatif dan R\&D. Bandung: Alfabeta.

Sugiyono. (2014). Metode Penelitian Pendidikan Pendekatan Kuantitatif, Kualitatif, dan R\&D. Bandung: Alfabeta

Sugiyono. (2016). Metode Penelitian Kuantitatif, Kualitatif dan R\&D. Bandung: Alfabeta.

Swastha, B. (2010). Manajemen Penjualan: Pelaksanaan Penjualan. Yogyakarta: BPFE

Tjiptono, F (2011). Service Management Mewujudkan Layanan Prima. Edisi 2. Yogyakarta: CV Andi.

Tjiptono, F. (2015). Strategi Pemasaran, Edisi Ke4. Yogyakarta: CV Andi.

Tunis, A.J., \& Martina, S. (2016). Pengaruh Kualitas Produk dan Harga Terhadap Keputusan Pembelian Di Thesecret Factory Outlet. Pariwisata, Vol. III No. 1 April 2016. ISSN: 2355-6587, e-ISSN: 2528-2220. 